Miami Nature Biotechnology Short Reports

TheScientificWorld (2001) 1 (S3), 137SR

ISSN 1532-2246; DOI 10.1100/tsw.2001.235

\title{
GENETIC CONTROL OF PROGRAMMED CELL DEATH IN C. ELEGANS
}

\author{
H. Robert Horvitz \\ Howard Hughes Medical Institute, Department of Biology, Massachusetts Institute of \\ Technology, Cambridge, MA 02139, USA \\ horvitz@mit.edu
}

\begin{abstract}
Apoptosis or programmed cell death is a major feature of the normal development of the nervous system. The clinical features of a variety of neurological disorders - including neurodegenerative diseases, stroke and traumatic brain injury - are a consequence of excessive neuronal cell death. One current hypothesis is that much of this excessive cell death involves the same mechanisms as those used during normal nervous system development. I will discuss findings concerning the mechanisms of apoptosis based primarily upon our studies of the nematode Caenorhabditis elegans. During the development of C. elegans, 131 of the 1,090 cells generated undergo programmed cell death. More than $80 \%$ of these cell deaths are in the nervous system. We have characterized developmentally, genetically and molecularly the roles of 15 genes that function in $C$. elegans programmed cell deaths. Six of these genes control the death process, six act in the phagocytosis of dying cells by their neighbors, and one functions in the digestion of the DNA of cell corpses; two additional genes specify which cells will or will not express this cell-death program. Many of these genes show structural and functional similarities to genes that act in mammalian apoptosis, indicating that the mechanisms of apoptosis are conserved among organisms as distinct as nematodes and humans. Our studies have led to a model for the developmental activation of programmed cell death in C. elegans: increased transcription of the egl-1 gene elevates the level of the EGL-1 protein, which is similar in sequence to the BH3-domain-containing cell-death killer proteins of mammals. The EGL-1 protein binds to a complex consisting of at least the CED-9 protein (similar to human Bcl-2) and the CED-4 protein (similar to human Apaf-1), releasing CED-4 and allowing it to activate the CED-3 caspase by promoting the proteolytic cleavage of a CED-3 proprotein.
\end{abstract}



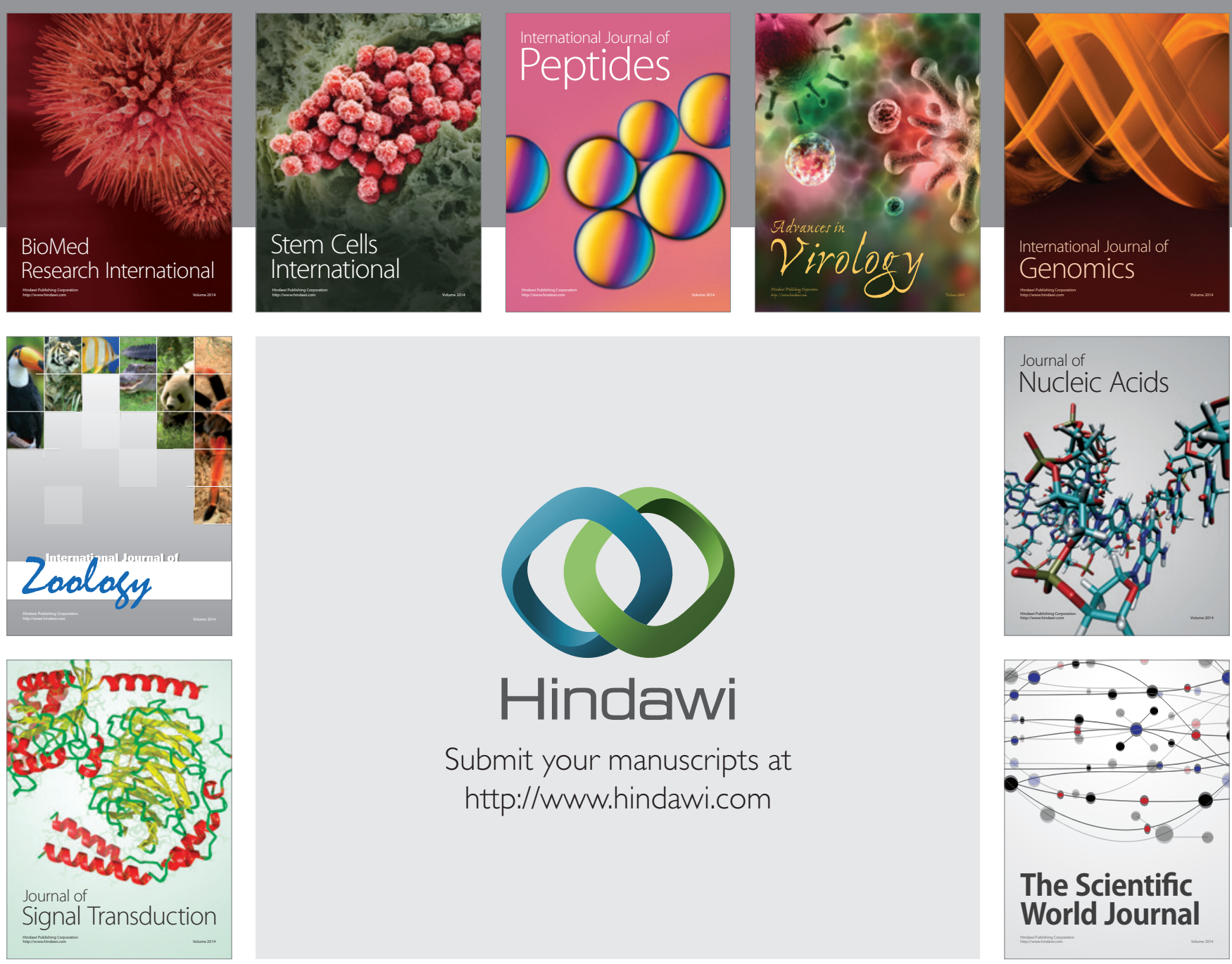

Submit your manuscripts at

http://www.hindawi.com
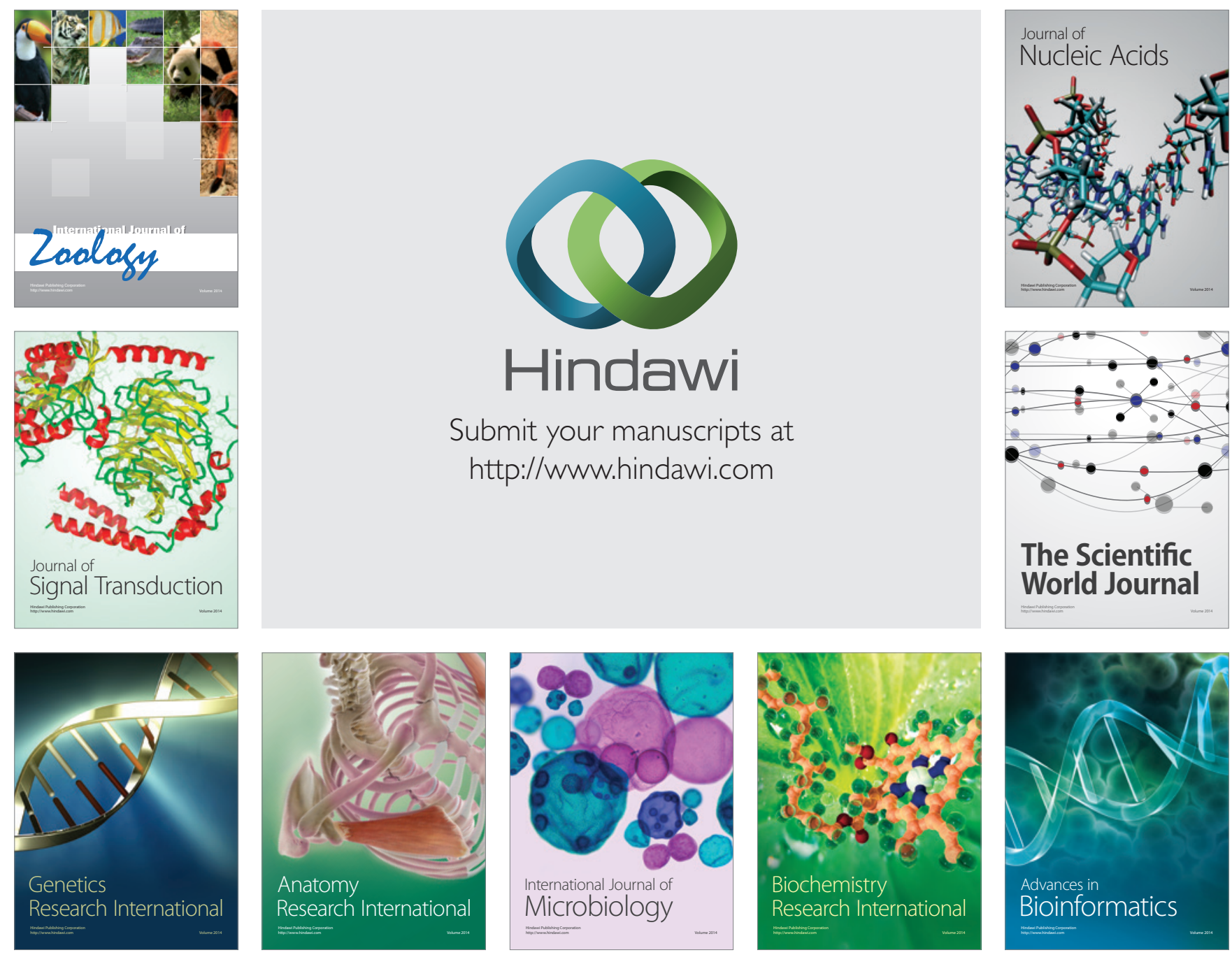

The Scientific World Journal
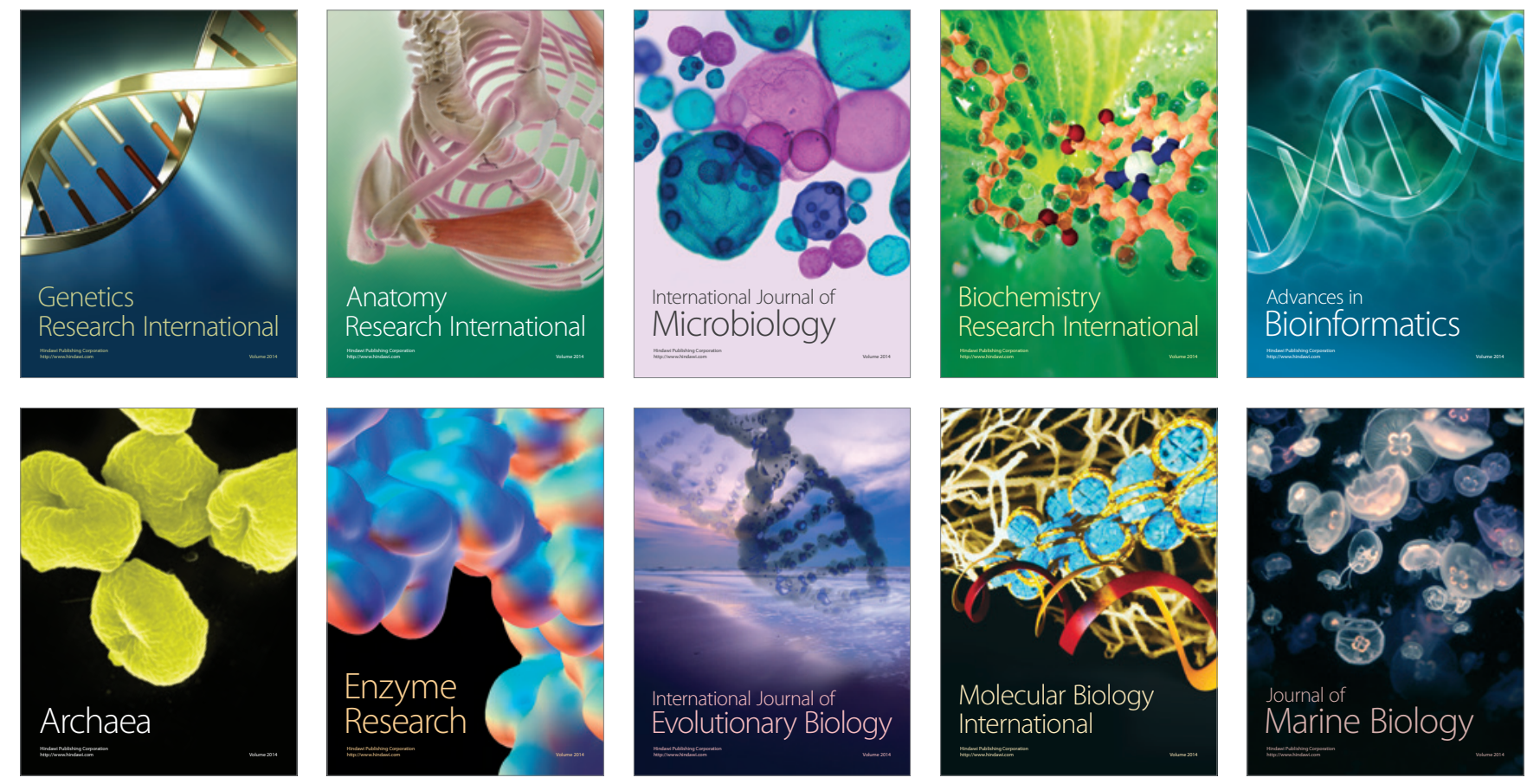